\title{
KONSELING KRISTEN TERHADAP WANITA YANG MENGALAMI KECANDUAN KERJA
}

\author{
Lilis Ermindyawati \\ Sekolah Tinggi Teologi Kanaan Nusantara \\ Jl. Kyai Sono No. 2, Genuk, Kec. Ungaran Barat, Kab. Semarang, Jawa Tengah \\ Email: lilis.ermind@yahoo.com
}

\begin{abstract}
Lilis Ermindyawati, Christian Counseling Against Women Experiencing Work Addiction. One phenomenon that occurs in the present are women addicted to work and this phenomenon is more of a negative impact than the benefits of women workers and those in the vicinity. Therefore, women need to be helped so addicted to work that they can get out of the problems they face. Christian Counseling is a solution to help women who are addicted to work. Every career woman is expected to have a balance between work, family and relationship with God. Women are not only successful in his work (his career), but also succeeded in fostering a harmonious household, educating children well, and has a close relationship with God.
\end{abstract}

Keyword: Christian Counseling, workaholic, working Addiction

ABSTRAK: Lilis Ermindyawati, Konseling Kristen Terhadap Wanita Yang Mengalami Kecanduan Kerja. Salah satu fenomena yang terjadi pada masa kini adalah wanita kecanduan kerja dan fenomena ini lebih banyak memberikan dampak negatif dibandingkan keuntungan yang diperoleh wanita pekerja dan orang-orang di sekitarnya. Oleh sebab itu wanita kecanduan kerja perlu ditolong agar mereka dapat keluar dari permasalahan yang mereka hadapi. Konseling Kristen merupakan solusi untuk menolong wanita yang mengalami kecanduan kerja. Setiap wanita karir diharapkan memiliki keseimbangan antara pekerjaan, keluarga dan hubungannya dengan Tuhan. Wanita tersebut bukan hanya berhasil dalam pekerjaanya (karirnya), tetapi juga berhasil dalam membina rumah tangganya yang harmonis, mendidik anak-anak dengan baik, dan memiliki hubungan yang erat dengan Tuhan.

Kata Kunci: Konseling Kristen, Workaholic, Kecanduan kerja

\section{PENDAHULUAN}

Di era zaman sekarang ini wanita karir kian lama semakin besar jumlahnya bila dibandingkan dengan 30 tahun yang lalu. Probabilitas wanita yang sadar akan pendidikan dan terbukanya kesempatan berkarir dapat menjadi faktor pendorongnya. Sangat disayangkan karena kesibukan bekerja dan mengejar karir makanya banyak wanita yang sampai "lupa" untuk menikah. Bahkan yang sudah menikah pun sampai mengabaikan suami dan anak-anaknya. Ada wanita yang memulai suatu pekerjaannya, tetapi tidak memiliki damai sejahtera sampai pekerjaan tersebut selesai. Mereka sangat asyik dengan obsesi yang tidak bisa diungkapkan dari benak mereka. Mereka merasa bersalah, bila hanya duduk-duduk saja, mereka menginginkan orang lain melihat bahwa mereka perfek dalam pekerjaan mereka, hingga tidak ada kesalahan dalam pekerjaan mereka. Aki- batnya mereka tidak banyak memiliki waktu untuk berbagi dengan keluarga maupun dengan temanteman yang lain.

Ada sebuah kasus yang terjadi pada sebuah keluarga yang terdiri dari seorang bapak, ibu dan anak. Ibu ini ingin bekerja untuk membantu perekonomian keluarga, supaya perekonomian keluarganya semakin meningkat, tidak hanya biasa-biasa saja. Tetapi sejak ibu ini bekerja sifat ibu ini semakin hari semakin berubah dan kelihatan suntuk dan tidak bersukacita. Menurut bapak tersebut (suaminya), istrinya tidak seperti dulu, karena terlalu sibuk dalam pekerjaanya, sehingga istrinya tidak memperhatikan suami dan anaknya. Dia sudah menjadi wanita yang kecanduan kerja yang selalu membawa pekerjaan kantornya ke rumah. Selain itu ibu ini juga melimpahkan kewajibannya sebagai ibu rumah tangga kepada pembantunya. Hubungan keluarga antara 
ibu, bapak dan anak seolah-olah terputus dan hampir tidak ada komunikasi yang baik, karena ibu ini terlalu sibuk dengan kegitan-kegiatan dalam pekerjaannya yang menyita waktu.

Ada juga kasus seorang wanita yang bekerja sebagai pemimpin di sebuah perusahaan swasta. Dia telah menikah dan memiliki dua orang anak yang masih balita, demi karirnya dia rela meninggalkan suami dan anaknya di luar kota dan pulang seeminggu sekali, jika libur. Hal seperti ini sangat disayangkan, karena menurut suaminya sebagai kepala keluarga, suaminya cukup mampu untuk membiayai kehidupan rumah tangganya, sehingga istrinya tidak perlu bekerja. Tetapi ibu ini tetap bekerja, tidak mengenal lelah, dengan alasan untuk menambah penghasilan keluarga.

Pertanyaannya adalah bagaimana menyelesaikan permasalahan tersebut? Melihat kasus yang terjadi, penulis merasa perlu menguraikan sebuah konsep konseling Kristen terhadap wanita yang mengalami kecanduan kerja. Melalui tulisan ini, penulis menguraikan konsep konseling Kristen terhadap wanita yang mengalami kecanduan kerja sehingga dapat dimanfaatkan dalam proses pembelajaran khususnya konseling Kristen dan pembinaan warga jemaat. Secara praktis, tulisan ini diharapkan dapat dimanfaatkan untuk pelayanan praktis konseling Kristen dan pembinaan warga jemaat

\section{METODE}

Penelitian ini adalah penelitian pustaka yang berangkat karena adanya sebuah kasus kecanduan kerja. Kasus tersebut mendorong penulis untuk memaparkan sebuah konsep konseling kristen terhadap wanita yang mengalami kecanduan kerja. Sumber primer dari penelitian ini adalah buku Teori dan Prinsip Konseling Kristen karya Rudy A. Alouw, Kehidupan Kristen Yang Sehat karya Frank Mirnith, Konseling Kognitif karya D.E. Naat, Pemulihan "Kecanduan Kerja” karya Juanita dan Dale Ryan.

Tahapan dalam penelitian ini adalah mengkaji sumber, kemudian diklasifikasikan sesuai de- ngan peta konsepnya. Hasil kajian ini kemudian dipaparkan dalam sebuah uraian sehingga dapat dimanfaatkan ketika menghadapi kasus kecanduan kerja dalam konteks pelayanan gereja dan masyarakat.

\section{TINJAUAN UMUM}

\section{Pengertian Konseling}

Secara umum "konseling" adalah sebuah proses pertolongan yang pada hakekatnya adalah secara psikologis antara seorang konselor terhadap seorang atau beberapa orang dengan maksud untuk meringankan beban penderitaan yang ditolong atau menemukan jalan keluar. Kata tersebut berasal dari kata counsel yang berarti nasehat. Konseling dapat didefinisikan sebagai berikut: konseling adalah hubungan timbal balik antara dua individu yaitu konselor yang berusaha untuk menolong atau membimbing dan konseli yang membutuhkan pengertian untuk mengatasi persoalan yang dihadapinya. Karena konseling ini bersifat Kristen maka aplikasi pemecahan masalah harus berdasarkan Alkitab, firman Allah. ${ }^{1}$

Konseling Kristen merupakan suatu proses pembimbingan yang dinamis dalam tuntunan Roh Kudus untuk menyampaikan nasehat, petunjuk, peringatan, teguran, dorongan dan ajaran dari perspektif Kristen (Alkitab), yang di dalamnya terdapat upaya meyampaikan pertimbangan yang memberikan kemampuan kepada konseli untuk membuat keputusan (sendiri) yang bijaksana yang membawa pemulihan, perubahan, serta pertumbuhan rohani. Menurut Meier, Mirnith dan Wichem tujuan konseling Kristen adalah (1) Menyelidiki problem, apakah masalah emosional, fisik atau spiritual; (2) Membantu konseli memperoleh pengertian mengenai masalahnya; (3) Membantu membuat rencana untuk menghadapi atau memecahkan persoalannya; (4) Menjadi

${ }^{1}$ Garry Collins, Konseling Kristen yang Efektif. (Malang: SAAT,1990), 3. 
orang Kristen yang bertumbuh imannya, yang nampak dalam hubungannya dengan Allah dan sesama. ${ }^{2}$ Sedangkan menurut Lawrence Crabb, tujuan konseling Kristen harus mencapai sasaran yaitu (1) Menyerupai seperti Tuhan. Ini adalah kebahagiaan yang sempurna yang dapat diperoleh melalui pemulihan hubungan dengan Allah; (2) Kedewasaan rohani yang melibatkan dua unsur yaitu ketaatan langsung dalam situasi atau keadaan khusus dan pertumbuhan atau perubahan karakter dalam jangka waktu panjang; (3) Perubahan psikologis harus nyata: perubahan batiniah dan perubahan tingkah laku menjadi tingkah laku yang Alkitabiah. ${ }^{3}$

Dari beberapa pendapat di atas dapat disimpulkan bahwa tujuan konseling Kristen adalah perubahan, pemulihan dan pertumbuhan. Apabila konseli yang dilayani belum beriman kepada Tuhan Yesus, maka mereka harus memperkenalkan siapa Yesus kepada konseli tersebut, sehingga konselor dapat memberi pengertian dan membimbing konseli sampai ia mengerti dan memahami pentingnya percaya dan beriman kepada Yesus. Konselor juga harus mengadakan pemulihan hubungan dengan Allah melalui penerimaan Yesus sebagai Tuhan dan Juruselamat secara pribadi kepada konseli tersebut. Seseorang yang bermasalah pasti mengalami distorsi, baik itu pikiran, perasaan maupun hati. Itulah sebabnya mereka harus dilayani dan dibimbing supaya mereka berubah sesuai dengan kebenaran Firman Allah.

Pertumbuhan rohani sangat penting bagi setiap orang Kristen, karena seringkali ada banyak masalah muncul akibat pemahaman yang keliru atau dangkal terhadap kebenaran Firman Allah dan janjijanji Allah yang ada dalam Alkitab. Salah satu aspek dari tujuan konseling yang perlu ditekankan adalah pertumbuhan rohani dan iman konseli. Dalam hal ini

${ }^{2}$ Paul D. Meier et.al., Pengantar Psikologi dan Konseling Kristen, Jilid 1 (Yogyakarta: PBMR Andi, 2004), 307-308.

${ }^{3}$ Lawrence Crabb, Effective Biblical Counseling, (Yogyakarta \& Bandung: Yayasan ANDI dan Kalam Hidup, 1995), 10-29. tujuan konseling untuk para wanita kecanduan kerja adalah supaya mereka dapat mengalami pemulihan dari kecanduan kerja. Para kecanduan kerja ini harus mengalami pemulihan supaya mereka berada di jalan kehidupan yang tidak hanya diisi dengan pekerjaan ataupun hanya bekerja terus menerus, tetapi juga dengan istirahat, berhubungan dengan orang lain, dan secara khusus dengan Allah sendiri. Mereka dapat dituntun, diarahkan untuk menemukan suatu kehidupan yang bebas dari rasa kesepian, tertekan dan depresi, akibat pekerjaan yang menyita waktu dan pikiran tanpa melepaskan pekerjaan itu sendiri.

\section{Pengertian Kecanduan Kerja}

Kecanduan kerja adalah suatu dorongan yang mengambil alih dari hidup seseorang. Kecanduan kerja telah menjadi bagian dari profesi atau bisnis bagi beberapa kalangan. Harga diri mereka terletak pada apa yang diartikan sebagai upaya mengejar target dalam pekerjaan. Prioritas orang yang kecanduan kerja seringkali terbalik, bahkan terkadang berubah-ubah. Obsesi hidupnya adalah bisnis atau pekerjaan dan pertemuan-pertemuan, makan siang, rapat-rapat, seminar-seminar, atau aktivitas yang lainnya, yang sudah cenderung menjadi gaya hidup. Secara umum, kecanduan kerja mengandung unsur compulsive atau addictif. Compulsif sendiri dapat digambarkan seolah-olah ada tekanan atau paksaan batin di dalam diri seseorang untuk terus bekerja. Sedangkan addictif adalah kecanduan atau ketagihan yang umumnya memiliki konotasi negatif, seperti: rokok, narkoba, dan lainnya. Hidup bagi seorang yang kecanduan kerja memang tidak ada jedanya. Mereka menghabiskan waktu berjam-jam di kantor, sehingga menimbulkan efek samping, seperti: kurang tidur, kelelahan, stres, serangan jantung, bahkan stroke.

\section{Faktor Penyebab Terjadinya Kecanduan Kerja}

Adapun faktor penyebab terjadinya kecanduan kerja adalah: 


\section{Kepribadian Obsesif Kompulsif}

Para wanita workaholic berasal dari kepribadian yang obsesif kompulsif, yang ditandai dengan kekakuan dan perfeksionisme dalam berbagai situasi. Orang-orang yang demikian ini, memiliki standar yang sangat kaku yang mengganggu penyelesaian tugas-tugas. Mereka cenderung terlalu syik dengan perintah, jadwal, peraturan dan perincian tugas sampai pada tahap dimana mereka kehilangan pandangan tentang kegiatannya. Mereka berpendapat bahwa orang lain harus melakukan sesuatu menurut cara mereka sendiri. Mereka begitu tekun dalam pekerjaan, sehingga tidak perlu waktu untuk rekreasi dan membina persahabatan dengan orang lain. Mereka cenderung tidak bias mengambil keputusan, menghindari atau menunda pengambilan keputusan selama mungkin dan terlalu teliti dalam hal nilai-nilai mereka (jauh melampaui tuntutan iman atau budaya mereka). Orang-orang yang demikian biasanya tidak punya perasaan, tidak bersedia memberikan waktu atau uang mereka kecuali mereka mendapatkan keuntungan tertentu dan merasa sulit membuang benda-benda yang tidak berharga.

\section{Memiliki Perasaan Tidak Berharga}

Kecanduan kerja merupakan kecanduan yang tidak sehat. Dalam hal ini kecanduanya adalah bekerja atau berkarir yang dilandasi oleh keyakinan bahwa dia adalah satu-satunya orang yang dapat melakukan pekerjaan dengan benar. Seringkali ini merupakan suatu tanda ketidakamanan atau ketidakmampuan dalam membuat prioritas. Dengan kata lain dapat disebabkan oleh adanya perasaan tidak berharga dalam dirinya, sehingga mereka ingin menunjukkan nahwa mereka berharga dengan bekerja keras dan berprestasi yang dihasilkan.

\section{Adanya Motivasi Untuk Mengejar Prestasi}

Para workaholic termotivasi ingin mengaktualisasi dirinya untuk mengejar prestasi atau kedudukan sehingga mereka benar-benar banting tulang mencari nafkah demi meraih hal itu. Biasanya tu- juannya juga beraneka ragam, tetapi yang paling banyak dikenal oleh banyak orang adalah mengumpulkan materi, mencapai kedudukan tertinggi, dan meraih prestasi terbaik. Semuanya bisa terpuaskan, tetapi manusia tetap terdorong untuk selalu bias melebihi apa yang telah dicapai.

\section{Adanya Keinginan Untuk Mengejar Harta}

Adanya keinginan untuk mengejar harta secara berlebih menjadi salah satu penyebab kecanduan kerja. Keinginan untuk mencari nafkah atau uang sebanyak mungkin sebagai suatu upaya untuk meningkatkan status ekonomi dan sosialnya.

\section{Sebagai Sebuah Pelarian}

Ada beberapa wanita yang dengan sengaja untuk menghabiskan waktunya lebih banyak di kantor dari pada di rumah. Bagai mereka kantor sangat dibutuhkan sebagai tempat melarikan diri dari berbagai tuntutan suami atau dari stres ketika menghadapi anak-anak mereka. Di tempat kerja mereka mendapat penghargaan atau pujian anak buah dan rekan kerja, tetapi di rumah yang terdengar hanyalah celaan suami dan mertuaserta tangisan anak-anak yang masih kecil. Di tempat kerja mereka mendapat pandangan kekaguman dari atasan, tetapi di rumah mereka mendapat cemoohan dari mertuanya. Di tempat kerja mereka menentukan agenda, sedangkan di rumah mereka diberi agenda. Hal itu berlangsung terus menerus, sehingga banyak wanita memilih untuk melarikan diri kepada pekerjaan. ${ }^{4}$

\section{Gejala Kecanduan Kerja}

Para pecandu kerja memiliki sebuah jadwal yang biasanya gila-gilaan atau sangat padat. Bekerja empat belas jam atau lebih dalam satu hari, itu merupakan hal yang tidak biasa. Mereka seringkali mencoba mengerjakan dua atau tiga perkerjaan sekaligus, memadatkan terlalu banyak acara ke dalam se-

${ }^{4}$ N.L. Gisler dan R. Douglass, Ensiklopedi Alkitab Masa Kini, Jilid I, (Jakarta: YKBK, 1995), 267. 
buah jadwal. ${ }^{5}$ Mereka mendedikasikan dirinya secara total pada karirnya. Mereka biasa kerja dengan beban kerja yang tinggi dan menghabiskan waktu yang panjang pula. Demi pekerjaan, mereka sering mengabaikan aktivitas maupun tanggung jawab lainnya. Bekerja dapat membuat mereka lebih senang dibandingkan dengan kegiatan-kegiatan yang lain. Mereka mencurahkan seluruh perhatian, tenaga dan waktunya pada pekerjaan.

Banyak orang tidak mengakui dirinya sebagai pecandu kerja. Mereka berdalih bahwa mereka memotivasi diri untuk sukses. Bekerja karena menyukai pekerjaan nya dan merasa bahwa bekerja itu penting untuk bermasyarakat. Para pecandu kerja tidak bisa membedakan antara pekerjaan dan tugas rumah. Meskipun berada di rumah, pekerjaan kantor tetap menjadi prioritas utama, terlalu memegang erat komitmen dan semangat kerja. Kebahagiaan mereka ada pada pekerjaan mereka. Pekerjaan selalu mendapat tempat yang lebih utama dari pada keluarga. Mereka tidak memiliki kehidupan sosial, kecuali kegiatan yang berhubungan dengan pekerjaan kantor.

Rekreasi dianggap pekerjaan yang membuang waktu yang harus dihindari. Kalaupun ada kegiatan tersebut masih harus berkaitan dengan pekerjaan mereka. Misal mengikuti kegiatan olah raga, tapi topik pembicaraannya masih seputar pekerjaan dalam usaha mencari peluang bisnis. Mereka seringkali mengabaikan kesehatan dan aktivitas yang tidak berhubungan dengan pekerjaan mereka. Para pecandu kerja biasanya mengalami kesulitan untuk mendelegasikan tugas atau pekerjaannya kepada orang lain, karena mereka tidak percaya kepada orang lain dengan alasan-alasan yang kurang logis.

\section{Dampak Kecanduan Kerja}

Kecanduan kerja dapat menimbulkan dampak yang tidak baik bagi kehidupan sendiri maupun hubungannya dengan keluarga dan orang lain, bah-

${ }^{5}$ Frank Minirth et al., Kehidupan Kristen Yang Sehat (Malang: SAAT, 2004), 320. kan hubungannya dengan Tuhan. Dampak yang diakibatkan karena kecanduan kerja meliputi dampak secara fisik, psikis, maupun spiritual.

\section{Dampak Secara Fisik}

Dampak kecanduan kerja sudah pasti merugikan kesehatan, karena mereka memacu diri terlalu keras tanpa beristirahat. Organ-organ tubuh akan bekerja melebihi kapasitasnya sehingga cepat rusak. Itulah sebabnya diterapkan peraturan jam kerja delapan jam sehari dan empat puluh jam seminggu. Ini ditetapkan agar manusia memperhatikan pula kehidupannya yang lain. Bekerja dengan giat memang bagus, karena akan memicu produktifitas dan membuahkan prestasi. Tetapi pola kerja yang kurang sehat dan tidak diimbangi dengan gaya hidup yang sehat, akan berpotensi memicu gangguan kesehatan. Pekerjaan yang menumpuk cenderung menyebabkan stres berkepanjangan. Beban pekerjaan yang berlebihan membuat pola hidup dan pola makan berubah. Dari hal inilah muncul rasa kuatir yang berlebihan sehingga bisa menyebabkan gangguan fisik, seperti gangguan di lambung. Penyebab gangguan di lambung disebabkan karena pola makan yang tidak teratur. Stres yang sering muncul akibat pekerjaan bisa juga memicu gangguan lambung, tepatnya pada usus dua belas jari. Para pecandu kerja yang sudah terbiasa dengan gaya hidup yang serba mengutamakan pekerjaan, akan sulit menyesuaikan diri dengan pola makan yang teratur. Sedikit saja pekerjaannya mengalami masalah akan timbul rasa cemas, bahkan stres yang mempengaruhi kinerja hormon pada lambung, ditambah lagi dengan makan yang tidak teratur, karena menyesuaikan jadwal kerja yang padat.

\section{Dampak Secara Psikis}

Dari sisi psikologi, para pecandu kerja akan mudah mengalami frustasi atau stres karena hanya memenuhi satu sisi kehidupannya, sedangkan satu sisi kehidupan yang lain diabaikan. Mereka cenderung memiliki ketidakamanan dan ketakutan akan kegagalan dalam berprestasi. Mereka juga kuatir 
atau cemas jika dipecat dari pekerjaannya, sehingga dalam hidupnya tidak ada kedamaian. Secara emosional, kerja cenderung cepat marah dan cemas jika penampilannya tidak sesuai dengan harapan. Mereka seringkali mengalami stres yang bersifat kronis, karena pekerjaannya. Akibatnya ada kecenderungan untuk mencelakai diri sendiri, bahkan bunuh diri, karena stres dan kelelahan.

\section{Dampak Secara Spiritual}

Dampak secara spiritual, dimana para pecandu kerja kurang bersedia meluangkan waktu untuk hal-hal kerohanian karena dianggap menyita waktu. Mereka akan merasa memiliki harga diri yang rendah di hadapan sesama dan Allah, karena harga dirinya diletakkan dalam pekerjaannya. Orang yang kecanduan kerja tidak rela membiarkan diri mereka tanpa bekerja karena akan menimbulkan perasaan tidak berharga dan terasing. Pada sebagian orang yang kecanduan kerja, mereka berusaha untuk menghindari kondisi, dimana mereka tidak bekerja. Ini terjadi karena persepsi yang berlebihan terhadap pekerjaan, sebagai satu-satunya hal yang paling dapat memberikan kebanggaan. Orang yang kecanduan kerja hampir tidak pernah mengambil waktu untuk menjadi tenang dan berdoa kepada Allah. Mereka tidak memiliki waktu lagi untuk Kristus dan firmanNya yang seharusnya menjadi standar dan tuntunan untuk segala sesuatu yang dikerjakan. Mereka tidak menempatkan Allah pada posisi pertama. Mereka tidak memberikan prioritas utama kepada Tuhan, dengan menyediakan waktu untuk memuji, menyembah dan memuliakan Tuhan.

\section{PENANGANAN TERHADAP WANITA YANG KECANDUAN KERJA}

Langkah konseling untuk menolong wanita kecanduan kerja adalah:

\section{Identifikasi Masalah}

Sebelum memberikan konseling, konselor perlu mengetahui masalah apa yang sebenarnya ter- jadi dan dialami oleh konseli. Tujuan dari mengidentifikasi masalah adalah untuk menolong konseli agar mengerti masalahnya secara sistematis. Dalam pelayanan konseling tidak pernah menemukan hanya satu masalah, tetapi selalu lebih dari satu masalah. Konselor bersama dengan konseli perlu meninjau ulang tentang perasaan, tingkah laku, dan pikiran konseli. Yang menjadi kesulitan bagi konselor, sebagian besar para pecandu kerja ini, tidak mengakui bahwa dirinya adalah seorang yang kecanduan kerja. Oleh sebab itu gejala-gejala yang mengarah pada kecanduan kerja perlu ditunjukkan dan dinyatakan kepadanya dengan penuh kasih, sehingga mereka dapat melihat masalahnya dengan jelas.

\section{Bimbingan Melalui Pengajaran Firman Tuhan}

Ketika konselor dengan konseli dapat dengan jelas melihat masalah yang dialami oleh konseli, maka konseli perlu mendapat bimbingan melalui pengajaran firman Allah. Perasaan yang salah harus diganti dengan perasaan Alkitabiah. Demikian pula dengan masalah tingkah laku yang bertentangan dengan Alkitab harus diganti dengan tingkah laku yang Alkitabiah. Pikiran yang salah yang sering menyebabkan stres dan depresi perlu diganti juga dengan pikiran yang Alkitabiah. ${ }^{6}$ Mereka perlu melihat dengan nyata kasih yang ia terima dari orang-orang yang mengasihinya, didasarkan pada siapa dirinya, bukan pada apa yang ia kerjakan. Nilai dirinya tidak didasarkan pada materi yang ia miliki. Ia perlu menyerahkan hidup sepenuhnya kepada Kristus dan firman Allah, yang mana seharusnya menolak standar dan tuntunan untuk segala sesuatu yang ia kerjakan. ${ }^{7}$

\section{Modifikasi Perilaku}

Metode selanjutnya dalam konseling kognitif adalah modifikasi perilaku atau terapi perilaku. Terapi perilaku menekankan perubahan perilaku bawaan (overt behavior). Modifikasi perilaku langsung

\footnotetext{
${ }^{6}$ Rudy A. Alouw, Teori dan Prinsip Konseling Kristen (Bandung: IAT, 2008), 99.

${ }^{7}$ Minirth, Kehidupan Kristen, 166-167.
} 
memimpin pada perubahan dalam perasaan dan sikap. ${ }^{8}$ Menurut Paul D. Meier pada dasarnya metode ini melibatkan ide modifikasi perilaku dengan mengubah konsekuensi dari perilaku itu dengan mengubah pendahulu perilaku tersebut (hal yang terjadi sebelum tindakan itu). Salah satu cara yang digunakan oleh pemberi terapi behavioral adalah sebuah kontrak, dimana antara konselor dan konseli menjalankan rencana dan tujuan tertentu diantara sesi konseling. ${ }^{9}$ Sehubungan dengan hal tersebut Juanita dan Dale Ryan Juanita, dalam bukunya Pemulihan "Kecanduan Kerja" memberi solusi terhadap para wanita yang mengalami kecanduan kerja diantaranya:

\section{Beristirahat}

Allah membangun dalam tubuh dan jiwa setiap orang, suatu kebutuhan untuk beristirahat. Semua orang perlu beristirahat secara teratur, walaupun mungkin hanya menghabiskan waktu beberapa menit untuk memperoleh sedikit udara segar ataupun berbincang-bincang dengan suami atau berbincang dengan seorang teman dekat. Jika seseorang membiarkan diri untuk beristirahat, pasti mereka akan dapat menjalani hidupnya dengan lebih baik dan dapat bekerja dengan lebih efektif.

\section{Menerima Bantuan}

Setelah beristirahat para wanita kecanduan kerja ini, diundang untuk menerima bantuan. Banyak wanita kecanduan kerja sebelumnya selalu dapat mengerjakan segalanya sendirian. Namun demikian bagi banyak orang hal itu menyebabkan semacam racun bersandar diri dan kepuasan yang kaku yang menyebabkan sulit untuk meminta bantuan atau menerima bantuan. Mereka perlu menyadari bahwa mereka membutuhkan pertolongan Allah dan meminta Allah menolong sepanjang perjalanan hidupnya. 2008), 6-7.

${ }^{8}$ D.E. Naat, Konseling Kognitif (Bandung: IAT,

${ }^{9}$ Meier, Pengantar Psikologi, 174-175.

\section{Menerima Kepuasan Sejati}

Kecanduan kerja banyak merampas keceriaan hidup yang sederhana. Jika memang benar bahwa apa yang terbaik dalam hidup ini adalah kebebasan, maka kecanduan kerja menghilangkan banyak hal yang terbaik dalam hidup, karena mengejar uang, kedudukan, keberhasilan, ataupun pengakuan.

\section{Bersikap Rendah Hati}

Rendah hati bukan berarti menganggap diri lebih buruk atau tidak berharga. Bersikap rendah hati berarti dengan jujur mengakui keterbatasan diri, belajar hidup dalam keterbatasan tersebut dan menyadari nilainya berasal dari Allah. Wanita kecanduan kerja perlu memohon kepada Allah untuk Allah peduli terhadap dirinya pada saat ia merasa kuatir, sehingga ada penghiburan dan sukacita di dalam dirinya.

\section{Berelasi Dengan Orang Lain}

Ketika hidup dianggap sebagai tugas untuk berhasil dengan sukses dan pekerjaan yang harus diselesaikan, maka berelasi dengan orang biasanya sulit, bahkan mereka selalu bersaing untuk mendapatkan perhatian dari orang lain. Mencoba berelasi dengan orang lain dalam kehidupan mereka, merupakan hal yang baik untuk dilakukan.

\section{Bergembira}

Kebanyakan para wanita kecanduan kerja sulit untuk bergembira dan mereka butuh waktu untuk melakukannya. Ada banyak rintangan untuk bergembira. Mereka berpikir bahwa bergembira adalah hal yang tidak efesien, tidak berguna, tidak perlu atau mengalihkan perhatian dari tujuan atau kewajiban. Allah mengundang setiap manusia untuk bergembira. ${ }^{10}$ Dari beberapa solusi yang diberikan kepada wanita kecanduan kerja, bila dilakukan dan dilaksanakan dengan baik, mereka akan dapat merasa-

\footnotetext{
${ }^{10}$ Juanita \& Dale Ryan, Pemulihan dari Kecanduan Kerja (Malang: Literatur SAAT, 2000), 34.
} 
kan manfaatnya. Mereka akan merasakan betapa ringan beban yang mereka alami selama mereka menjadi orang yang dapat memanfaatkan waktu dengan baik, tanpa harus mengurbankan orang lain.

\section{KESIMPULAN}

Manusia harus bekerja untuk memenuhi kebutuhan hidupnya. Memang itulah yang dikehendaki oleh Allah. Alkitab mendukung para wanita untuk bekerja. Para wanita harus bekerja dengan rajin, jujur, taat kepada atasan, dan dengan tulus hati. Wanita bekerja hanya untuk menambah penghasilan suami, maka seorang wanita harus dapat membagi waktu antara pekerjaan, keluarga dan hubungannya dengan Tuhan. Para wanita yang memiliki pekerjaan di luar rumah diharapkan tidak menghabiskan waktunya hanya untuk pekerjaannya. Disela-sela kesibukannya dalam pekerjaan, mereka harus dapat membina hubungan mereka dengan keluarga, dan juga diharapkan dapat melayani pekerjaan Tuhan. Kecanduan kerja dapat dialami oleh setiap wanita karir, terutama mereka yang memiliki kepribadian obsesifkompulsif, memiliki perasaan tidak berharga, memiliki motivasi untuk mengejar prestasi dan harta. Jika dilihat dari hasil kerja yang ditunjukkan, wanita kecanduan kerja tergolong memiliki komitmen yang tinggi terhadap pekerjaan, sehingga cenderung tidak puas dengan hasil kerja yang "biasa-biasa" saja. Standar kerja yang tergolong tinggi mendorong untuk berusaha keras mereka dapat mencapainya. Kondisi ini dapat juga dipengaruhi oleh lingkungan kerja

\section{DAFTAR RUJUKAN}

Alouw, Rudy A.. Teori dan Prinsip Konseling Kristen. Bandung: IAT, 2008.

Collins, Garry. Konseling Kristen yang Efektif. Malang: SAAT, 1990.

Crabb, Lawrence. Effective Biblical Counseling. Yogyakarta \& Bandung: Yayasan ANDI, dan Kalam Hidup, 1995.

Gisler N.L. \& R. Douglass, Ensiklopedi Alkitab Masa Kini, Jilid I. Jakarta: YKBK, 1995. yang kompetitif, dimana kesempatan untuk promosi lebih sulit jika mereka tidak terlihat menonjol. Wanita yang kecanduan kerja dapat menimbulkan dampak yang tidak baik dalam kehidupannya sendiri maupun hubungan dengan keluarga dan orang lain.

Secara fisik, para pecandu kerja akan mengalami gangguan lambung atau bahkan tekanan darah tinggi yang dapat mengakibatkan serangan jantung, jika kenyataannya tidak seperti apa yang diharapkan. Secara psikis, mereka cenderung mengalami stres dan depresi yang kemungkinan dapat menyebabkan bunuh diri. Mereka cenderung tidak memiliki hubungan yang dekat dengan Allah, karena prioritas utama hanyalah pekerjaan. Pada kenyataannya, fenomena ini lebih banyak memberikan dampak negatif dibandingkan keuntungan yang diperoleh oleh wanita kecanduan kerja. Oleh karena itu, wanita kecanduan kerja perlu ditolong melalui bimbingan konseling, agar mereka dapat keluar dari permasalahan mereka. Seorang wanita kecanduan kerja, harus menyadari bahwa dirinya dinilai bukan berdasarkan apa yang mereka lakukan dan apa yang mereka miliki, tetapi karena memang mereka berharga dimata Allah. Oleh sebab itu mereka perlu menyeimbangkan antara pekerjaan dan rumah tangganya, serta hubungan dengan Allah. Ketika mereka dapat menyeimbangkan ketiga hal tersebut, mereka dapat menjadi wanita karir yang sukses dalam karir, tanpa harus mengorbankan keluarga dan hubungan pribadi dengan Allah. Selanjutnya mereka akan dapat menjalani kehidupan mereka dengan penuh sukacita.

Juanita \& Dale Ryan. Pemulihan dari Kecanduan Kerja. Malang: Literatur SAAT, 2000.

Meier, Paul et.al., Pengantar Psikologi dan Konseling Kristen, Jilid 1. Yogyakarta: Andi, 2004.

Minirth, Frank et al., Kehidupan Kristen Yang Sehat. Malang: SAAT, 2004.

Naat, D.E. Konseling Kognitif. Bandung: IAT, 2008. 